\title{
CULTURAL ADAPTATION OF ACEHNESE AND ETNIC CHINESEE IN BANDA ACEH, FROM INTERCULTURAL COMMUNICATION PERSPECTIVE
}

\author{
SUZY AZEHARIE, WULAN PURNAMA SARI \& KELTY TJHIN
}

\author{
Lecturer, Faculty of Communication, Tarumanagara University, West Jakarta, Indonesia
}

\section{ABSTRACT}

As a special region called the Veranda of Mecca, Aceh is a unique province and it differs from others in Indonesia, for the implementation of Islamic law in the region. In fact, there are many ethnic groups, who live in Aceh. One of them is ethnic Chinese. A majority of ethnic Chinese lives in Peunayong region of Banda Aceh, located near a port. The research studies, cultural adaptation of the Acehnese and ethnic Chinese in Banda Aceh, from Intercultural Communication Perspective. It also studies obtacles in the communication process, as the centre of this cultural adaptation. The research uses descriptive qualitative methods, through a case study approach, in order to see the cultural adaptation of the Acehnese and ethnic Chinese, as well as its obstacles. The research will use in-depth interview for seven informants, from the Aceh ethnic group and ethnic Chinese. The research data are obtained from the in-depth interview, observation and documentation data. The research results indicate the occurrence of cultural adaptation in a form of language, behavior, social tradition as well as culture. Despite there have occurred the cultural adaptation, the obstacles still occur. The obstacles occur in a kind of prejudice, stereotype and etnocentrism between the two ethnic groups. Moreover, the obstacles rises as well, when the government is involved in this matter. It bans some celebrations, such as Christmas Day and New Year.

KEYWORDS: Cultural Adapatation, Acehnese, Ethnic Chinese \& Intercultural Communication

Received: Sep 12, 2017, Accepted: Sep 30, 2017, Published: Oct 13, 2017, Paper Id: IJCMSOCT20178

\section{INTRODUCTION}

As a special region called the Veranda of Mecca, Aceh is the western most province of the Unitary State of Republic of Indonesia (NKRI). Aceh is the only one province that, the central government has given authority to stipulate Islamic law called Qanun and implement the Islamic syariah for the devotees. Aceh is called the Special Region because, according to Musni Umar (2002:1) Aceh is the first region, where Islam entered into Indonesia and the region, where the Colonial Countries from Netherlands, Portugal, United Kingdom to Japan were difficult to colonize.

Despite Acehnese society is under the Islamic law, there are other ethnic groups, who live together with them, i.e. ethinic Chinese. According to Kong Yuanzhi (2000:98), it is estimated that, ethnic Chinese entered Aceh for the first time around the 12nd century. As the diplomacy envoy from China visited Aceh in 1409 and on this occassion, it awarded the gift of Cakradonya bell as the friendship symbol between Aceh and China, to Aceh's Sultan. Moreover, Sulaiman et.al (1988:22) writes that ethnic Chinese entered Aceh massively in 1875, when the colonial Netherlands took them to work as labor and most ethnic Chinese, in Banda Aceh came from Khek tribe (Hakka) in Kwantung Province. 
A majority of ethnic Chinese in Banda Aceh lives in Peunayong, near a port. Houses of ethnic Chinese in Peunayong are close to each other. Word Peunayong comes from the two words of peu and payong, and it means to protect each other. In the past Peunayong was the place, where Sultan Iskandar Muda gave asylum or received his visitors from Europe and China. When it is near Peunayong port located, in the cornet of the town, ethnic Chinese unload goods in the port before they distribute. In Peunayong there are four temples for Buddhists and three churches for Christians, and four mosques for Muslims. (Kampung China di Aceh Itu Bernama Peunayong, 2014).

The two ethnic groups either Acehnese or ethnic Chinese, lives together and absolutely they do intercultural communication and cultural adaptation. According to Huber W. Ellingsworth, in the dissertation of Ilya R. Sunarwinadi with the title of Social Communication, in Intercultural Adaptation, it is stated that, the intercultural communication occurs in the centre of cultural adaptation (Sunarwinadi, 1993:28).

The researchers want to know, therefore, cultural adaptation between Acehnese and ethnic Chinese in Banda Aceh and we see it from the intercultural communication perspective, with the formulation research of (1) How do Acehnese and ethnic Chinese carry out cultural adaptation, in Banda Aceh?; (2) What obstacles do occur when Acehnese and ethnic Chinese, carry out intercultural communication?

The research is carried out on the basis of two main theoretical concepts, i.e. cultural adaptation theory from A. Rani Usman (2009: 45) and theory of intercultural communication barriers, in a kind of social prejudice (Liliweri, 2011:175), stereotype (Liliweri, 2011:177-178) and ethnocentrism (Samovar, et.al., 2010:214). Several paragraphs below, will discuss the theoretical concepts.

According to William A. Haviland (1999: 348-350), the cultural adaptation term is a condition that, an individual has to survive in circumstances, without the use of anatomical and physiological characteristics but culture, in order to develop and provide a variety of environments. The cultural adaptation is the human condition, to adapt to culture believed and conducted in the circumstances.

A. Rani Usman (2009: 45) states that, effective communication with people of different culture is definitely expectable, for cultural adaptation. In other words, the adaptation to culture occurs in a form of language, behavior and social tradition. Gudykunts \& Kim, 2003 (2003:361) states that, the centre of this cultural adaptation is based on communication process, when it occurs in and through communication. Acehnese and ethnic Chinese have interacted and communicated in the period of hundred years, so the cultural adaptation has been successful. The research describes how the cultural adaptation between two ethnic groups, occurs in a kind of language, behavior and social tradition.

Lilian Chaney and Jeanette Martin, as quoted in Lusiana Andriani Lubis (2013: 6) explain that, the differences of culture and experience can cause intercultural communication barriers. It is firstly because, the culture relates to different ethnic groups and religions, as well as social differences. Secondly, individual experiences are not similar, and therefore, the perception and individual concept differ, when they see and consider something. The barriers can be from social prejudice, stereotype and ethnocentrism.

G. W Allport in Alo Liliweri (2011: 175) states that, in the beginning, social prejudice is the statement on the basis of experiences and untested decision, in advance. It changes from the like vs dislike and the supported vs unsupported scale, in some circumstasnces. However, it shifts right now. The prejudice turns to emotional and negative viewpoint, to some individuals or groups. 
A stereotype is a belief of people concerning an individual, or a group as a way of considering them, on the basis of social strata or grouping they make themselves. According to A. W. Gerungan, in Alo Liliweri (2011:177-178), the stereotype is any description, or response on personal characteristics, or behavior from members of another group with negative image and the prejudiced individuals have had it, before they have a chance of doing normal friendship, with those who are imposed on the stereotype.

Serena Nanda and Richard L. Warms, as quoted in Samovar, et.al (2010:214) describe ethnocentrism, as the viewpoint that an individual's culture is superior than another. In other words, it states that, another culture is considered on the basis of the individual's cultural standards. The individuals are ethnocentric, when they see another culture through their cultural glasses, or social position. Men have natural tendencies to use their own culture, to see others' behavior.

Acehnese and ethnic Chinese, undergo some barriers when they do cultural adaptation, as described as above. Thus, the researchers will do the research, with the above factors to see the intercultural communication barriers, between Acehnese and ethnic Chinese in the existing cultural adaptation.

\section{RESEARCH METHODS}

The research uses descriptive qualitative methods, through case study because; it observes the phenomenon as a unique case and difficult to be found, in another place. According to robert k. Yin (2013:1), the case study is a research method, that triggers questions on how and why to be asked in a research, when the researchers only have little opportunities to the occurrence and focus on the contemporary phenomenon, in the context of real life.

The research location is carried out in banda aceh, i.e. In kuta alam sub-district. The sub-district is located in banca aceh city and a majority of ethnic Chinese, and Aceh lives here. The data collection method is carried out through indepth interviews, observation, library study and online-data search. The interview is carried out to 14 informants, of whom seven come from ethnic Chinese and the others are from Acehnese.

The following informants who come from ethnic chinese are: yuswar (key informant), freddy kurniawan, akhie, sheilisa, chua wen lung, achong and muhammad husein or aliung. Moreover, seven acehneses consist of Zainal Abidin (key informant), a. Rani usman, bangman, teuku kemal faisal, norma, ratieh puspa sari, bella raisa nariski.application of panel data analysis.

\section{FINDINGS AND RESULTS}

As the capital city of Nanggroe Aceh Darussalam Province, visitors and businessmen from India, Middle East countries and China have visited Banda Aceh. Cultural contact or interaction of various nations occurred before Christ and until, the early year of Christ happened in Lamuri Kingdom or known right now, as a Banda Aceh City. The life of Lamuri society (Banda Aceh) in the early of Aceh civilization, had established a kingdom with advanced governance. Moreover, due to the strategic position of Malacca Strait or Hinda Ocean, trade life in Banda Aceh was popular. International society with different cultures, races and nations traveled across Malacca Strait and stopped by in the region. They did political or business partnership. The kingdom of Lambri or called Banda Aceh recently, existed from the 9th century to the 12 nd century. It was a kingdom with great power in Indonesia because, it had good management and diplomatic relationship with the world. It can be seen from the relationship of the Kingdom of Lambri, with great nations in the world such as China (Usman, 2009:132). Therefore, it can be stated that, for hundreds of years ago, since ethnic 
Chinese migrated to Aceh, the two different ethnic groups have done social interaction and intercultural communication.

The Aceh ethnic group is a major ethnic group, who live in all regions in Aceh, such as Sabang Kotamadya, Banda Aceh, Aceh Besar District, Pidie, North Aceh, East Aceh, West Aceh and South Aceh. It has its own language, i.e. Aceh language with a variety of dialects, i.e. Peusangan, Banda, Bueng, Daya, Pasee, Tunong, Matang, Seunangan and Meulaboh. In general Acehnese society can understand word meaning of sentences of those who come from the different dialects (Umar, 2006:69).

The cultural system of Acehnese society gets deep influence from Islam. However, before Islam entered into Aceh in the first Hijri year, Hindu and Buddha, from India and Kong Hu Chu from China had influenced the cultural system. Moreover, after Islam grew fast in Aceh, the influence of Hindu, Buddha, and Kong $\mathrm{Hu} \mathrm{Cu}$ of which, against the aqidah was totally forbidden. Therefore, these religions only slightly influenced Acehnese society, such as traditional cloth, language and traditional events. After Islam came to Aceh, social, state and cultural system in Aceh got the color from Islam (Usman, 2009:293). Therefore, according to Fikar W. Eda and S. Satya Dharma, the Acehnese ethnic group has one special characteristic, that closely ties as its main identity, i.e. Islam. Aceh ethnic group and Islam, become two sides of a coin and it is difficult to separate because, it has colored Acehnese society in their daily life (Eda and Dharma, 1999:6).

According to A. Rani Usman (2009:159), ethnic Chinese are an ethnic group, who is known to do migration all around the world. Migration motivation of the Chinese ethnic group is among others, due to political, economic and security reasons in their ancestral land. However, the economy is the main reason of many ethnic groups in China, to migrate from their China's land. The ethnic Chinese who migrate to Asia, i.e. Taiwan, Hong Kong, Singapore, Malaysia and Indonesia, included in Nanggroe Aceh Darussalam reaches 80\%. It occurs because, the Southeast Asia region is fertile and strategic region in international trade. The entrance of ethnic Chinese society to out of Chinese land, is estimated to occur in thousands of years. Therefore, ethnic Chinese society who lives outside Chinese land is called Migrated ethnic Chinese or Huaqiau.

Moreover, ethnic Chinese came to Aceh in great number. Colonial Netherlands took them as labor, in 1875. Ethnic Chinese located in Aceh province, and in Banda Aceh city, especially mostly came from Khek (Hakka) tribe in Kwantung Province (Sulaiman, et.al., 1988:22). Ethnic Chinese migrating to Banda Aceh, have settlement called Peunayong as discussed in the Introduction.

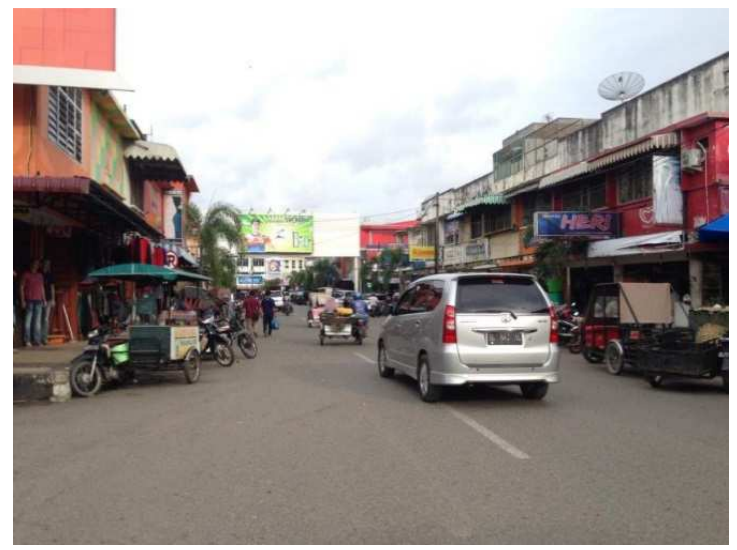

Figure 1: Condition in Peunayong Region in Banda Aceh

Source: (The researcher's documentation on November 19, 2016) 
The next paragraphs will explain the research, results on cultural adaptation between the two ethnic groups, i.e. Acehnese and ethnic Chinese. According to A. Rani Usman, cultural adaptation involves individual adaptation to language, behavior and social tradition being different from those who have the culture. The cultural adaptation not only occurs among foreigners to local culture, but also local people who make it to the entrance of foreign culture (Usman, 2009:276).

According to A. Rani Usman in Sejarah Peradaban Aceh as well, language is a means of communication in society and verbal expression, used to convey some willingness in society. Moreover, language is an element of culture. Acehnese born and grown in Banda Aceh, usually use Acehnese language. Acehnese language is their mother tongue and main language, used in communication with other Acehnese. Acehnese language is the majority language in Banda Aceh because, all Acehnese speaks the language in Aceh (Usman, 2003:31).

Based on the observation results of the researchers to Acehnese in Banda Aceh, they can speak the Acehnese language better than Bahasa Indonesia. Acehnese definitely appreciates and maintain Acehnese language, as their mother tongue. Therefore, Acehnese language is a symbol of identity for their ethnic group. There is no Acehnese who cannot speak their language. Acehnese language has been part of Acehnese's inseparable identity. In their social life Acehnese, frequently makes interaction with ethnic Chinese, who live in Banda Aceh. The social interaction and communication occur between Acehnese and ethnic Chinese, in traditional markets, school or shops owned by ethnic Chinese and Acehnese in Banda Aceh.

Through the observation results the researchers make, it is known that, ethnic Chinese who get together in Peunayong market usually use Khek language, when they interact with other ethnic Chinese. Moreover, Acehnese uses Acehnese language mixed with Bahasa Indonesia, when they interact with other Acehnese and ethnic Chinese, in Peunayong market. As Acehnese history expert and Acehnese, the key informant Zainal Abidin who live in Gamong Laksana Peunayong in his daily activities, frequently interacts and comminacates with ethnic Chinese, states that, due to their settlement in environment, who live mostly ethnic Chinese, Acehnese can understand a few words of ethnic Chinese's language, i.e. Khek language. Moreover, there is some Acehnese who fluently speaks in Khek language. It is in line with the interview results to other informants, i.e. A. Rani Usman, Head of Research and Development Centre, Indonesia, Islamic University in UIN Banda Aceh and Bella Raisa Nariski, an Achenese student whose age is 21 years old and daily activities frequently interact with ethnic Chinese.

Moreover, according to the interview results with the ethnic Chinese informant, Freddy Kurniawan, an employee whose age is 21 years old and daily activities, frequently interact with Acehnese states, that he has no complaint if he should make communication and use Bahasa Indonesia. Moreover, he has no problem if Acehnese cannot talk in Khek language.

All interview results with informants show that, there is any cultural adaptation in a form of language between Acehnese and ethnic Chinese. It is in line with the cultural adaptation theory presented by William B. Gudykunst dan Young Kim Yun (2003) that, in the cultural adaptation the individuals need a learning in a kind of condition and social communication process, such as training the encoding of verbal and nonverbal language.

Moreover, the cultural adaptation in a form of behavior is shown in inclusiveness and tolerance in the habit of cloth wearing behavior. Banda Aceh has different habits of cloth wearing behavior if compared from other cities. It occurs after Islamic syariah orders all Muslim to cover their aurat (parts of the body that Islam orders to cover), by wearing proper 
Muslim cloth.

The legal system called Qanun or known as Islamic Syariat is a local law, that regulates the implementation of local government and their life activities in Acehnese Province including Banda Aceh. It can be seen further on www.dpr.go.id regarding Special Autonomy for Special Province of Aceh, as Nanggroe Aceh Darussalam Province.

The interview results with Zainal Abidin explains that, ethnic Chinese in Aceh wear cloth politely, although they do not wear jilbab (headscarf). It is appropriate for the interview with Informant Sheilisa, Head of Methodist Chinese School Banda Aceh, who explains that ethnic Chinese in Banda Aceh adapts in wearing of clothing, by wearing polite and neat cloth; however, there is no necessity to use jilbab for non-Muslim.

Moreover, the cultural adaptation in a form of tradition, of ethnic Chinese to Acehnese is carried out in a kind of adapting it, to the existing tradition in Aceh, i.e. a tradition tightly devoted to Islamic teaching. The religious elements in the traditional art of Barongsai look similar to some rituals, and these are disappearing. As a result, Barongsai does not only become exclusively to ethnic Chinese. Acehnese can participate in it as well. The researchers can conclude that, there is a sense of equality whenever ethnic Chinese do in the cultural adaptation, with Acehnese. It indicates that, there are equality and balance of Chinese culture realized in the traditional art of Barongsai among ethnic Chinese in Banda Aceh.

Through observation the researchers do, furthermore, it finds that, there are some ethnic Acehneses, who participate in the traditional art of Barongsai. According to the statement uncovered by the informants from ethnic Chinese and Acehnese, it can be concluded that, there is cultural adaptation that Acehnese do to ethnic Chinese in a form of active participation, in Barongsai tradition as a part of ethnic Chinese life. The participants of Barongsai tradition in Banda Aceh are firstly only among ethnic Chinese, and it gets a negative reaction from Acehnese. However, the refusal does not go along because, Acehnese realize and learn coexisting with other cultures. It occurs until right now, and Barongsai does not become foreign acts again, for Acehnese. Currently the traditional art of Barongsai has been growing.

Together with the cultural adaptation that Acehnese does, they can develop the traditional art of Barongsai, together with ethnic Chinese. Acehnese shows the elements of openness, support, positive sense and equality for ethnic Chinese through their active participation in the traditional art of Barongsai.

Furthermore, according to the observation conducted by the researchers in Banda Aceh, to a unique habit and it probably cannot be carried out in other cities in Indonesia, i.e. the closure of shops owned by Acehnese and ethnic Chinese in Banda Aceh every Friday before Jummah prayer time. Thus, all activities stop during the Jummah prayer time. Besides of the cultural adaptation as described as above, religion is a cultural adaptation as well. It is seen that, some ethnic Chinese in Banda Aceh have embraced Islam as their religion.

Despite Acehnese and ethnic Chinese have done cultural adaptation through language, social tradition and behavior, the observation the researchers have done finds that, there are some barriers in intercultural communication between Acehnese and ethnic Chinese in Banda Aceh. The interview with Informant A. Rani Usman, Head of Research and Development Centre, Indonesia, Islamic University in UIN Banda Aceh shows that, ethnic Chinese still have enthnocentrim tendencies through feeling and viewpoint. They consider that, Chinese culture is more superior than other cultures, so they consider other cultures on the basis of their cultural standards. Ethnic Chinese show it to Acehnese through the unwillingness of teaching Khek language as their identity, language to Acehnese in Banda Aceh.

On the other hand, Acehnese definitely do not want to eat at ethnic Chinese restaurants. It gets support from the 
statement of Informant Zainal Abidin in the interview. He says that, Acehnese is worried about the possibility of pig oil or fat in the served food, at the restaurants. On the basis of the statement the researchers conclude that, there is any stereotype and its negative viewpoint Acehnese give to ethnic Chinese. As an effect, it directs to attitude and behavior from Acehnese to their unwillingness of visiting ethnic Chinese restaurants. It is based on the viewpoint that, the served food contains some ingredients forbidden by Acehnese as devoted Muslim. Moreover, there is prejudice Acehnese have to ethnic Chinese that, ethnic Chinese definitely relate to communism and have arrogant attitude. However, the stereotype disappears, when they do a lot of interaction and communication. So they can understand each other. The researchers conclude that some social prejudices from Acehnese, occur if they infrequently interact and get together, with ethnic Chinese in Banda Aceh. Therefore, the negative social attitude to other races or ethnic groups influence individual behaviors.

The barriers also appear from the government policy. It issues some laws and regulations, that forbid Muslim society to celebrate Christmas and New Year (Warsidi, 2015). Based on the statement at above, the researchers conclude that the government policy and culture can influence cultural adaptation, carried out by ethnic Chinese and Acehnese. Moreover, the researchers conclude that, the any government policy has some effects of social life of the Acehnese and ethnic Chinese, when they make interaction each other and do the intercultural communication process.

Based on all research results, there is a model of cultural adaptation between Acehnese and ethnic Chinese in Banda Aceh as follows:

Table 1: Cultural Adaptation Model of Acehnese and Ethnic Chinese

\begin{tabular}{|c|l|l|l|}
\hline No & \multicolumn{1}{|c|}{ Cultural Adaptation } & \multicolumn{1}{|c|}{ Interaction } & \multicolumn{1}{|c|}{ Obstacle } \\
\hline 1 & Bahasa & Openness & Etnocentrism \\
\hline 2 & Behavior & Support & Social Prejudice \\
\hline 3 & Tradition & Food & Stereotype \\
\hline
\end{tabular}

\section{CONCLUSIONS}

Ethnic Chinese had migrated to Aceh since the 13rd century, when Admiral Cheng Ho visited Samudera Pasai, an Islamic Sultanate in Aceh. In the official visit, Admiral Cheng Ho gave a gift of Cakradonya Bell as the friendship symbol to Sultan Zainal Abidin. Moreover, the Sultan of Samudera Pasai, i.e. Sultan Zainal Abidin officially sent his brother to China as a goodwill visit.

Therefore, cultural contact between Aceh people and ethnic Chinese have occurred for hundreds of years. From the points of analysis, the researchers have described in the previous chapters, there are some conclusions to be made:

- Cultural adaptation between Acehnese and ethnic Chinese occurs through language, tradition and behavior for a long of period. However, the cultural adaptation from Acehnese occurs for those who have inclusive values and frequently interact to ethnic Chinese.

- Despite there is Qanun as the Islamic law in daily laws and regulations of Acehnese society in Banda Aceh, ethnic Chinese who live in Banda Aceh appreciate and follow the existing laws and regulations despite there are some compulsion attitudes among ethnic Chinese.

- Life of ethnic Chinese and Acehnese society in Banda Aceh is relatively secure despite Aceh was in conflict. 
However, it does not influence the life of ethnic Chinese and Acehnese in Banda Aceh.

- There are some social prejudices and stereotypes from Acehnese who infrequently make interaction with ethnic Chinese in Banda Aceh.

- There is ethnocentrism from ethnic Chinese to Acehnese, and it can be seen from the reluctance to teach Khek language to Acehnese.

\section{ACKNOWLEDGEMENTS}

The authors are grateful to all the sources and Tarumanagara University, especially Faculty of Communition for all the support and assistance to carry out this research work.

\section{REFERENCES}

1. DPR. (n.d.). Retrieved November 15, 2016, from www.dpr.go.id:http://www.dpr.go.id/dokjdih/document/uu/UU_2001_18.pdf

2. Kampung China di Aceh Itu Bernama Peunayong. (2014, Januari 31). Retrieved November 08, 2016, from Detik News: https://news.detik.com/berita/d-2484137/kampung-china-di-aceh-itu-bernama-peunayong

3. Eda, W. Fikar dan S. Satya Dharma. (1999). Aceh Menggugat Sepuluh Tahun Rakyat Aceh Di Bawah Tekanan Militer. Jakarta: PT Penebar Swadaya.

4. Gudykunts, W. B., \& Kim, Y. Y. (2003). Communicationg With Strangers An Approach To Intercultural Communication (4th ed.). New York, USA: McGraw-Hill Companies, Inc.

5. Haviland, A. William. (1999). Antropologi. Jakarta: Erlangga.

6. Liliweri, Alo. (2011). Gatra- gatra KomunikasiAntarbudaya. Jakarta: Pustaka Belajar

7. Lubis, Lusiana Andriani. (2014). Pemahaman Praktis Komunikasi Antarbudaya. Medan: USU Press.

8. Samovar, Larry A., Richard E. Porter., \& Edwin R. McDaniel. (2010). Komunikasi Lintas Budaya: Communication Between Cultures. Jakarta: Salemba Humanika.

9. Sulaiman, dkk. (1988). Perdagangan, Pengusaha Cina, Perilaku Pasar. Jakarta: Pustaka Grafika Kita.

10. Sunarwinadi, Ilya R. (1993). Komunikasi Sosial dalam Adaptasi AntarbudayaSuatu Studi tentang Peranan Penggunaan Media Massa dan Faktor- Faktor Lain yang Menemukan Kemampuan Komunikasi Antar Pribadi Warga Masyarakat Indonesia di Tokyo dan Jepang. Disertasi. Universitas Indonesia: Jakarta.

11. Umar, Muhammad. (2006). Peradaban Aceh (Tamaddun) I: Mengulas Kisah Sejarah Aceh dan Adat. Banda Aceh: Yayasan Busafat.

12. Umar, Musni. (2002). Aceh: Win-win Solution. Jakarta: Forum Kampus Kuning.

13. Usman, A. Rani. (2009). Etnis Cina Perantauan di Aceh. Jakarta:YayasanOborIndonesia.

14. Warsidi, A. (2015, Desember 29). Banda Aceh Haramkan Perayaan Tahun Baru. Retrieved November 25, 2016, from Tempo Online: https://nasional.tempo.co/read/news/2015/12/29/058731452/banda-aceh-haramkan-perayaan-tahun-baru

15. Yin, R. K. (2013). Studi Kasus: Desain dan Metode. Jakarta: PT. Raja Grafindo Persana.

16. Yuanzhi, Kong. (2000). Muslim Tionghoa, Cheng Ho. Jakarta: Pustaka Populer Obor. 